This is a pre-print. This material has been published in The Ethics of Citizenship in the 21st Century, edited by David Thunder, Springer, 2017, pp. 29-48 https://doi.org/10.1017/CBO9781316145340.013 Please cite the published reference.

\title{
Civic Motivation and Globalization: What is it Like to Be a Good Citizen Today?
}

\author{
Simon Keller, Simon.Keller@ vuw.ac.nz
}

\begin{abstract}
Good citizenship is often associated with patriotism. The patriotic citizen identifies deeply with her country and has a primary and far-reaching loyalty to the country. In the $21^{\text {st }}$ century, forms of identification that support patriotic citizenship are increasingly undermined. State boundaries play an ever smaller role in forging citizens' identities, in defining citizens' moral horizons, and as sites of the political problems with which citizens are most concerned. But there are still good reasons to want people to be good citizens, even if they cannot be patriotic citizens.

What could take the place of patriotic citizenship? This paper sketches a model of the "wordly citizen." The worldly citizen does not identify primarily with her country, but she nevertheless holds a strong derived commitment to her state, grounded in an accurate understanding of her place in her local community and the wider world. Worldly citizenship, the paper argues, is both recognizable and achievable. It stands as an attractive alternative to patriotic citizenship, and also to the "global citizenship" associated with strong forms of cosmopolitanism.

KEYWORDS: Citizenship; Patriotism; Civic Virtue; Globalization; Special Relationships.
\end{abstract}




\section{A troubled virtue}

Good citizenship is an important virtue, from two points of view. It is essential to the health of the state; a flourishing state requires good citizens. It is also a central personal virtue; it is difficult to imagine someone who is a good person but a bad citizen. Good citizenship is also a fairly transparent virtue, in one respect. It is not difficult to say in broad terms what it means to be a good citizen. A good citizen cares about others, follows the law, contributes to community life, and upholds the values of a just state.

Yet, good citizenship is, in other respects, a puzzling virtue. It is a virtue that essentially involves partiality. As a good friend is partial to her own friends and a good parent is partial to her own children, a good citizen is partial to her own state. Virtues of partiality can be puzzling because it looks as though to have such virtues is to treat certain others differently in response to morally arbitrary characteristics. My children are not more valuable than other children, just because they are my children, but, to the extent to which I am a good parent, their being my children leads me to give them better treatment. Virtue, sometimes, involves partiality - but does it not then also involve a kind of blindness to the rights and interests of others? In the case of the good citizen: if I have a special commitment to the flourishing of my own state and its citizens, do I then turn away from the rights and interests of other states, and of other people, just because they happen not to be "mine?"

There are extra reasons to be troubled by the partiality involved in good citizenship, as compared to the partiality involved in good friendship, good parenting, and so on. For one thing, to be a good citizen is to give a special priority to people with whom you are not acquainted. When you are partial to your child, at least you know your 
child and are intimately aware of his value and his needs. As a citizen, you commit yourself to a polity almost all of whose members you will never meet. You can respond directly to your child or friend in a way in which you cannot respond directly to (most of) your fellow citizens. For another thing, good citizenship involves a direct concern with justice, arguably to a greater extent than do other kinds of partiality. A good friend or parent might be moved mostly by a concern to treat her friend or child well, not because she thinks her friend or child morally deserves it, necessarily, but just because she cares about her friend's or child's interests. The good citizen, though, acts out of a sense of duty to her state and her fellow citizens, and has a concern with justice within her state and with giving each of her fellow citizens their moral due. It is puzzling, again, to say how a virtuous person could have a concern that is explicitly about justice, but is also restricted to one state over others and to one group of people over others.

If there is a real puzzle here, then two familiar ethical treatments of citizenship can be interpreted as attempts to solve it. The first treatment says that in its most mature and ethically defensible form, citizenship is not focused on a particular state but rather on humanity or the world as a whole: we should aspire to be world citizens. That story resolves the puzzle by omitting arbitrary partiality from citizenship, but it betrays its contrivance in its own label. What sense does it really make to speak of being a "world citizen?" To say that you are from the world, or that your political community is the world - that sounds as much like being a citizen of nowhere as being a citizen of everywhere.

The second strategy for resolving the puzzle is to reject the assumption that the real perspective of justice and morality is an impartial perspective. Standards of justice 
arise from within particular communities, we might say, so there is nothing arbitrary or morally obnoxious about the citizen's paying special attention to the community in which her own sense of justice and her own moral identity are grounded - where that community receives its political expression through a state. ${ }^{1}$ There are various stories that can be told in filling out the details of this strategy, one of which I will come to later, but a worry about all those stories is that they look anachronistic in a globalized world. It is difficult to maintain, these days, that the individual's "home" is coextensive with any particular state, and hence difficult to say why we should expect a citizen to see the moral world essentially from the perspective of her own state. It is then difficult to justify her giving special moral attention to those who happen to be within her state's borders, just out of a claim about where her sense of justice comes from.

My goal in the present paper is to explain in more theorized terms the puzzle facing the virtue of citizenship and then to outline a more promising strategy for resolving the puzzle. I want to proceed through an examination of the good citizen's states of mind. What does a good citizen care about? What motivates her? What does she

\footnotetext{
${ }^{1}$ In this paper I will try to avoid controversial commitments over what makes something a country and what makes something a state, but I assume that there are differences between a country, a state, and a government. Putting things roughly, a country is something like Spain or Australia: it is compounded out of a relationship between a given territory, a landscape, a community of humans that exists over time, and a distinctive history. A state is an essentially political administrative structure, usually associated with a country: a state claims authority a territory, sets and enforces laws, has its own set of rules and decision-making procedures, recognizes certain people as its citizens, and claims to be the political representative of a country its people. A government is made up of particular people and policies and governs on behalf of, or with the authorization of, a state: a government cannot outlast a state, but a state can and usually does outlast a government. It is possible to love a country without loving the state through which the country is given its political expression, and it is possible to approve of a state without approving of the government that governs on behalf of the state presently.
} 
believe? To what and to whom is she loyal? With what and with whom does she identify? Our emotional and cognitive lives are complex and there are many different ways in which we could be motivated to perform any given action. Informed by an appreciation of the various psychological profiles that could lead a person to act as a good citizen, I want to suggest, we can construct a model of good citizenship that supports genuine state citizenship but does not look anachronistic or misguided in the modern world.

What beliefs, emotions, and motivations should we hope for in a citizen today? I want to distinguish two approaches to this question: one beginning with the nature of the flourishing state and the other with the nature of the flourishing person.

\section{Serving the state}

The first approach asks what citizens can do to help the state flourish. A good citizen, on this way of looking at things, is one who acts in such a way as to make the state better. If we think that a flourishing state is an orderly state, for example, then we will say that a good citizen follows the laws. The good citizen will also perform other acts, such as paying her taxes, supporting important community organizations, looking out for vulnerable fellow citizens, and defending the state when it is under threat. In describing the psychological life of the good citizen, then, we can start by asking which beliefs, emotions, and motives will most reliably lead to the performance of acts that help a state to flourish.

Based on that consideration only, it is a contingent question what psychological life we should hope for in a citizen. In the Republic, Socrates recommends that citizens should be told a "noble lie": they should be led to believe that their fellow citizens are 
their siblings and their country is their parent. ${ }^{2}$ That is a lie, but it is a useful lie, because citizens who believe it are more likely to defend the country and more likely to make sacrifices to contribute to the country's flourishing. Socrates' claim aside, the point is that a citizen who has false beliefs or misguided emotions might thereby be more likely to act in ways that help make the country flourish. It may turn out that the best citizen will falsely believe that her country is the best in the world, will wrongly take her identity to be intimately connected with her country, or will have a wholly arbitrary preference for her fellow citizens over other people: perhaps those are the mental states that best produce acts that contribute to the flourishing of a state.

There is another dimension to the task of serving the flourishing state, however, when the flourishing state is imagined to be democratic. In a democracy, the citizen's actions are not just instrumentally related to the state's flourishing but also help constitute its flourishing. A flourishing state is a legitimate state, and a democracy derives its legitimacy from having its citizens govern themselves. So a citizen who serves her state's flourishing will participate in the state's deliberation and government. To contribute in a constructive manner - to participate in a way that leads to the state's being a just state and making good decisions for good reasons - the citizen will need to have right-minded values, at least to some extent, and will need to engage in informed and judicious decision-making.

A good citizen in a democracy, then, cannot be a robot: it is not enough that the citizen performs the acts that contribute to the state's flourishing. The citizen must be a

\footnotetext{
${ }^{2}$ Republic 414b. Translators sometimes call the noble lie the "royal lie" or "magnificent myth."
} 
good believer and deliberator, at least over some domains. Nevertheless, when we characterize the good citizen as one who best serves the flourishing of a country, we take the value of good citizenship and the value of the psychological life behind it to be ultimately instrumental. We start with a picture of the flourishing country, then we slot in citizens who will help the country conform to that picture.

\section{Flourishing as a citizen}

The second approach to the task of describing the psychological life of the good citizen begins with ideas about the flourishing person. When we think about what it means to be a good person, we can ask how a person flourishes within various roles. We can ask what it means to flourish as a lawyer, for example, or as a teacher, athlete, musician, or philosopher, and we can ask what it takes to flourish as a parent or a student or a retiree. Asking what it takes for a person to flourish within a particular role, we need to ask, among other things, how that role can fit into a flourishing human life more broadly. On the question of what makes for a flourishing citizen, we need to ask how it is possible for a person to do well in her role as citizen, where her doing well in that role is an aspect of her flourishing as a human.

One component of human flourishing is having correct beliefs and right-minded values. To the extent to which a person's beliefs are false and her deliberations misguided, she fails to perform well the characteristically human activities of forming beliefs and values and making decisions. Beginning from the question of what it takes for an individual human to flourish in her role as citizen, then, there is an intrinsic reason, not just an instrumental reason, to want her beliefs, values, and motives to be correct, or 
appropriate, or right-minded. If we conclude that a good citizen must have false beliefs or misguided emotions and motives, then we will have to conclude that good citizenship comes at a sacrifice: a good citizen cannot be a fully flourishing human.

That said, it remains possible that in describing the psychological life of the good citizen, we will choose beliefs, emotions, and motives for their instrumental value, even at the cost of their correctness. Perhaps humans cannot handle the truth. Perhaps an accurate view of our place in the world would leave us depressed or listless or antisocial. An attempt to describe the psychological life of the good citizen, following this second approach, must balance consideration of the consequences of particular mental states against consideration of their correctness. It is at least conceptually possible that a person will be a better citizen for lacking self-knowledge, say, or for lacking a clear-eyed view of her own country.

We now have two questions to ask. First: what psychological states are most likely to cause a person to perform the acts that most contribute to the flourishing of the state? Second: what is the nature of the mental life of the flourishing person who is (as part of her overall flourishing) a flourishing citizen? One problem for citizenship in a globalized world is that under prevailing accounts of citizenship, our answers to those two questions are likely to come apart.

\section{The case for patriotic citizenship}

What is patriotism?

If you want to make someone into a good citizen of her state, you might try to make her into a patriot. A patriot loves her country and is loyal to her country, so a patriot 
can be expected to be motivated to do what is best for her country, and hence to advance the flourishing of her country, in its political manifestation as a state. Patriotism is all around us; it appears to be a natural form of human loyalty, and a relatively easy one to inculcate. The model of the patriotic citizen probably stands as the most common and recognizable model of the mental life of the good citizen: a good citizen, so understood, has many virtues, but insofar as she is a good citizen and not just a good person, perhaps her most important characteristic is her patriotic commitment to her country.

Patriotism involves particular forms of love and loyalty. Not just any kind of loyalty to your country allows you to count as a patriot. There are commonalities between patriotism and other familiar forms of love and loyalty, like love between family members and friends and loyalty between colleagues and teammates. Due to its focus upon the state, however, and its importance for shared political life, patriotism has its own distinctive character. In what follows I try to identify the main motivational and cognitive elements of patriotism, as they bear upon the connection between patriotism and citizenship. ${ }^{3}$

Patriotism, first, involves a kind of identification. If you are a patriot, then you take your connection with your country to say something about who you really are. A patriot of France thinks of herself as, in a deep respect, French. An Australian patriot takes his being Australian to matter for his own self-understanding. As a result of identifying with a country, a patriot characteristically feels the distinctively patriotic

\footnotetext{
${ }^{3}$ In describing the psychology of patriotism here, I lay out some claims that I defend in more detail in chapter 3 of my The Limits of Loyalty (Cambridge University Press, 2007); and on pages 51-59 of my 'The Case against Patriotism,' in John Kleinig, Simon Keller, and Igor Primoratz, The Ethics of Patriotism: A Debate (Wiley Blackwell, 2015).
} 
emotion of pride in country. The patriot sees her country's virtues and achievements as reflecting, somehow, on her. She can feel pride in her country's virtues and achievements, almost as though they were her own virtues and achievements. The patriot may also feel shame, even embarrassment and humiliation, in her country's failings. To some extent, at least, the patriot sees a little bit of the country in herself and a little bit of herself in the country. This form of identification with country allows a patriot to feel intimately involved in the fate of her own country, and hence of the state of which she is a citizen, and to share with fellow citizens the common bond of identity that can allow a group of disparate people to form a political community.

The patriot, in addition, is willing to make sacrifices for her country. The patriot's concern for her country's interests may compete with and sometimes outweigh her concerns for her own interests and the interests of others for whom she cares. Patriotism, to put it another way, involves a serious commitment to country. The patriot does not see her relationship with her country simply as useful, or simply as a source of fun. She takes her country's interests to provide her with weighty reasons for action. That is why a patriot can be expected to do what advances the flourishing of her state, even when inconvenient, and even when inconsistent with her immediate interests.

Entangled with the patriot's commitment to country is a view about what her country is. The patriot does not commit herself to her country just because it is her own, but also because she takes it to have features that make it worthy of her allegiance. When a French patriot thinks of France, she thinks of it as a country worth defending. Characteristically, the patriot's commitment to her country takes the form of a commitment to an ongoing national project, which usually incorporates the project of 
achieving ongoing political independence through the maintenance of a sovereign state. A national project of the relevant kind has its roots in the country's history and sets conditions for the country's flourishing in its own distinctive manner. The French patriot may be committed to the flourishing of France as a secular country, the New Zealand patriot to the flourishing of New Zealand as a bicultural country, and so on. To be a patriot, at least usually, is to have a sense of what is good and distinctive about your own country, and hence of what it would take for your country to succeed on its own terms. This makes sense of the specialness of the patriot's commitment to the flourishing of her state, and the particularized standards that her patriotic commitment to country invokes. An Italian patriot, for example, does not simply have a concern for seeing good things happen to Italy and Italians, more than to Germany and Germans; she has a sense of what it would take for Italy to flourish in its own distinctively Italian manner, and of why its flourishing in that manner is something to be valued.

That said, patriotism does not involve slavish devotion to a national project, or to a state. There is such a thing as patriotic dissent. When a person criticizes her country from the standpoint of a patriot, she criticizes the country for failing to live up to its own values, or for failing to be the best that it - in all its distinctiveness - can be. Also, there is room for political and cultural disagreement among patriots. Patriots may disagree about what is good about their country, about how their national project is best understood, and about what it would take for the country to flourish on its own terms. The political contribution of the patriot may include participation in the conversation about what her country truly is and how it could truly flourish. 


\section{The usefulness of patriotism}

Where a good citizen is construed as a citizen who serves the flourishing of the state, there is then clear reason why we might expect patriotism to contribute to good citizenship. Accordingly, states have often construed the task of creating good citizens, and indeed the task of creating a state, as the task of creating patriots. Through various means, but especially through the education system, the state may try to inculcate patriotic beliefs and feelings. To make a person patriotic, you need to give him a certain understanding of himself; patriotic education involves encouraging people to identify themselves as members of an ongoing community that is represented by the state - to see themselves as Italian, for example. You also need to make him willing to make sacrifices for the state; patriotic education involves establishing service to the state as a virtue - it may glorify those who have made sacrifices for the glory of Italy. And, you need to make him proud of his country, in its guise as a country with its own distinctive virtues; patriotic education involves telling a story about the nature of the country on which the country is special and good - it may tell of the special value of the Italian way of life.

The inculcation of patriotism in the service of good citizenship may be used to confront both localism and globalism. Where people are seen to be committed more to their own regions than to the state, patriotic education may focus on forging a larger national identity. Its main message may be that "we are all Italians," for example: it may tell the individual that his character and future are tied to his country, not his local

community. Where the concern is that people are in danger of having no communal identification at all - of understanding themselves simply as individuals or just as inhabitants of an enormous world - patriotic education may seek to build a sense of 
community and social solidarity. Its main message may be that "we (as opposed to they) are in this together." But the project of nurturing patriotism, in any case, is largely the project of nurturing certain beliefs, emotions, and motivations. That is why patriotic education involves learning about the country and its history, as well as involving songs, ceremonies, and symbols. Patriotic education manufactures opportunities for people to have a particular way of seeing their country and the world, and a particular cluster of feelings.

\section{How patriotism can be correct}

If patriotism can be effective in building citizens who advance the flourishing of the state, can it also build humans who flourish in the role of citizen? What is the connection between patriotic citizenship and human flourishing in general? These are tougher questions.

A cosmopolitan picture, gestured at earlier in this paper, says that patriotism, no matter how useful, is not an element of human flourishing. State boundaries, runs the argument, are morally arbitrary. No one gets to be a better person or to have different rights or to matter more just because she is from one country rather than another. The correct moral identity, on this story, is your identity simply as a human, or as a rational agent. When the patriot ties her moral identity to her country, when she takes a special concern for her own state and fellow citizens over others, and when she sees things from the point of view of her own country, she - on this story - fails morally. Perhaps she 
helps her state to flourish, but she herself does not see things correctly and thereby fails to flourish as a moral agent. ${ }^{4}$

In opposition to that cosmopolitan picture, however, has been developed a different way of thinking about moral identity and the nature of morality, which is closely associated with the defense of patriotism. In his classic paper "Is Patriotism a Virtue?" Alasdair MacIntrye mounts parallel defenses of patriotism and anti-liberal communitarianism. ${ }^{5}$ He says that a person's moral sensibility cannot be separated from the truth about where and from whom he learned his morality, and that the most powerful and attractive form of moral motivation comes from within a community-oriented perspective. While MacIntyre presents his view of moral agency as an attack on liberalism, many liberal philosophers accept his basic insights and seek to incorporate them into a more nuanced liberal perspective, and along the way find liberal justifications for patriotism and other forms of group loyalty. ${ }^{6}$

When it comes to the defense of patriotism, the crucial claim for MacIntyre is that the country can be a moral community, and so the state can embody and speak for a moral community. States, often, are the entities most responsible for our education, moral and otherwise. Whether you are on one or the other side of a state border can make a significant difference to how you are taught. Countries also provide a focus for political

\footnotetext{
${ }^{4}$ For versions of this criticism, see Paul Gomberg, 'Patriotism is Like Racism,' Ethics 101 (1990): 144-150; Martha Nussbaum, 'Patriotism and Cosmopolitanism,' in Nussbaum and Joshua Cohen, For Love of Country? (Boston: Beacon Press, 2002) pp. 320; and Peter Singer, One World (Newhaven: Yale University Press, 2002) ch. 5. ${ }^{5}$ The 1984 Lindley Lecture, reprinted in Igor Primoratz (ed.) Patriotism (Amherst: Humanity Books, 2002) pp. 43-58.

${ }^{6}$ See, for example, Yael Tamir, Liberal Nationalism (Princeton University Press, 1995); and Anna Stilz, Liberal Loyalty (Princeton University Press, 2011).
} 
and social life; which country you come from determines for whom you can vote, in what form you can participate in politics, and how multiple aspects of your life are formed and administered. A country also connects you with a distinctive political tradition and a distinctive way of life. It can provide you with an understanding of what it would mean for you to flourish, within the social context from which you emerge.

If we accept that there is a link between a person's moral education and background and her proper moral perspective and identity, then we can - if we are following MacIntyre's argument - picture the patriot as seeing herself and the world correctly. Instead of saying that the patriot is morally blinded or moved by arbitrary considerations, we can say that the patriot shows self-understanding and has a clearsighted and robust source of moral motivation. If you are an Australian patriot, for example, then you may be quite correct in identifying yourself primarily as an Australian, in having a special concern for Australia, and in being motivated by thoughts like "this is what an Australian would do." To flourish as a human, surely, is partly to understand who you really are. If the patriot has genuine self-understanding and moral motivation and if the perspective of impartial morality involves alienation and fails to engage with real human motives - then patriotism may indeed be a requirement for good human flourishing, and not a moral mistake at all.

A consequence is that when we provide people with a patriotic education, we can, in the right circumstances, "make it true" that patriotism, for them, is the correct moral attitude. Patriotic education can create moral identities. If it is successful, then it may be self-legitimating. By making you think of yourself as deeply Italian, I may help make it 
the case that your identity is deeply Italian. I might make it right and proper for you to see the moral world from an Italian point of view.

Let me note again that the vindication of patriotism just sketched does not need to be tied to a self-consciously anti-liberal perspective like MacIntyre's. One way to see this is to see that the source of morality and moral motivation need not determine morality's content: not completely, anyway. From your essentially embedded perspective - your perspective as an Australian, say - you may find reason to care about the rights of all humans, Australian or not; you may commit yourself to the flourishing of Australia as a liberal democracy; you may think that the distinctively Australian concerns that define your identity are concerns with equality and fairness, as manifested in a distinctively Australian context. ${ }^{7}$

\section{Problems for patriotism, problems for citizenship}

The state remains the most significant political institution in the modern world. The human world is divided into states. The individual's political experience and the conditions of her political life are determined largely by her state. States are where people vote and can seek to attain the highest political office. Mostly, the parties to international treaties and agreements, and to international dramas and conflicts, are states. The most powerful individuals in the political world are the leaders of states. If you want to change something important in the world, you will probably have to do it by trying to change states.

\footnotetext{
7 These sorts of thoughts inform Igor Primoratz's defense of "ethical patriotism." See chapters 3, 6, and 9 of Kleinig, Keller, and Primoratz, The Ethics of Patriotism: A Debate.
} 
As a result, the health of human life in the present world depends deeply upon the health of states. Human life is better and more just where states are better and more just. Whether individuals are able to be happy, to express themselves, to live comfortably, to self-govern, to exercise religious choice, and so on, depends largely upon the character of the states under which they live. It is common to say that in a globalized world, states are not as important as they used to be. Perhaps that is true, but states are still very important, and much more important than any other kind of institution when it comes to the political lives of individuals and of the world as a whole.

Still, there are contemporary phenomena that threaten the state, in some sense at least. People move more easily between states, and many states have large immigrant communities. As a result, states tend to be less ethnically and culturally homogenous than they perhaps once were; it is not so clear that boundaries between states mark boundaries between kinds of people. There exist more transnational institutions, like the European Union, and more free trade agreements and international trade bodies, which accumulate political and financial power that would once have been held by states.

Further, people's attention - so it seems - is less and less constrained to their own countries. We are increasingly aware of ourselves as facing global problems. Problems like climate change involve activities carried out in some countries having their greatest effects on other countries, and require truly international solutions. The sources from which we get our news and entertainment are less and less likely to be shared with our fellow citizens; iconic national newspapers and television stations are disappearing or losing business to more scattered providers, and many of us get most of our news from websites and television stations based overseas. It is easier to follow sports leagues 
overseas, to watch foreign television, and to form communities that cross state boundaries.

To some extent, surely, all of these phenomena are largely about perception. We have long faced transnational political, environmental, and financial problems. Probably, our countries have never been as homogenous and unified as some people would like to believe. We probably still in fact get a decent proportion of our news and entertainment from within our own countries. But when it comes to questions of identity and loyalty, perception matters.

When people are aware of themselves as sharing experiences and problems with people overseas as much as at home, and when people do not consider their experience of the world to be essentially the experience of a citizen of a particular state, it becomes much harder to make them identify with their countries. To give a stylized example: when a person is preoccupied with the problem of climate change, reads the New York Times online, stays up late to watch English football on the web, spends time exchanging YouTube clips with similarly minded people all over the world, and faces a serious question about whether to seek university education or a job in a different country, it is difficult to make him understand himself as deeply and essentially Australian.

It is no longer so easy to represent states as representatives of moral communities. The country is no longer such a natural source of deep moral identity, or of moral motivation. From an individual's point of view, it is harder for her to think of her country as special and distinctive, or as representing a single particular way of life, or as making her the person she is. From the state's point of view, in the face of the individual's awareness of her country as just one among many, it is harder to "make it true" that she is 
deeply connected to her own country and hence to a state, as a matter of her very identity. As a result, the model of patriotic citizenship - the most familiar and natural model of good state-centered citizenship - does not appear to capture humans as they are. In today's world, among today's citizens, it is harder to see how patriotic citizenship can underlie a robust and accurate form of identity and self-understanding.

Here, then, is my statement of the puzzle of citizenship in the globalized world. We still have every reason to wish for acts of good citizenship, because states are still so politically important; but it is no longer reasonable to wish for people to display the psychological profiles that (we have always thought) make them likely to perform those acts, because people do not identify so naturally with their countries. States still matter and still require committed citizens, but it no longer makes sense to expect people to identify deeply with their own countries and to be committed state citizens as a matter of that identity. If we are asking what it takes for the state to flourish, then we want citizens who treat their own state as special. But if we are asking what it takes for individuals to flourish, then we do not want citizens whose moral horizons are limited by the boundaries of the country: such citizens, in the twenty-first century, would misunderstand themselves and their moral world.

\section{$\underline{6 .}$ Forms of commitment}

Under the model of patriotic citizenship, the citizen serves the state out of feelings of loyalty. She takes herself to have a special self-constituting relationship with her country, and she honors that relationship by committing herself to the country's 
flourishing. Her commitment to her country is entangled with her sense of the country as hers: that, partly, is what makes it a commitment of loyalty.

The patriotic citizen's commitment to country is a primary commitment, not a derived commitment. It is not as though the patriot cares first about something distinct from the country - a value or a project or a region or a person - and then commits herself to the country because (and on condition that) the country contributes to that distinct thing about which she cares. A person might care, for example, about freedom and democracy, and may support her country because (and on condition that) it serves the values of freedom and democracy - but that is not the commitment of a patriot. A patriotic citizen is committed to her country in the first instance or for its own sake, not as a consequence of her commitment to something else.

It makes sense to think that a robust commitment to country, of a kind that can motivate acts of good citizenship, will be a commitment of loyalty to the country for its own sake. But there are commitments of quite different kinds that often, in other contexts, produce acts that contribute in positive ways to the flourishing and success of an institution (or other kind of entity). You can be strongly committed to something, and can act well towards it and contribute to its flourishing and success, without being loyal to it, and without having a primary commitment to it.

Imagine the commitment you might have to a political party. You might be strongly committed to the party. You might be emotionally invested in it and prepared to give up your time and money to help it achieve its goals. Yet, your commitment to the political party may be derived from more fundamental commitments to other things. You might support the party because it sets out to protect the lifestyle or the region you love, 
or because it does the best job of standing up for the values you care about. If the party were to change, so that it no longer protects your beloved lifestyle or region or the values you care about, then you might be ready to abandon it. If the party were to fall apart, but to be replaced by a different party that did a better job of protecting the things you care about, then that might be a perfectly happy result as far as you are concerned. And, it may be that you are not really loyal to the party, exactly: your commitment to it may have nothing to do with any sense that it is yours. But your commitment to the party, derived from your deeper commitments to other things, may nonetheless be very strong.

(This is not to say, of course, that nobody is ever committed to a political party as a matter of primary loyalty. There are those who do see their identities as entangled with a particular political party and who are committed to the party in the first instance, not just for what it does or supports. But I am not talking about them.)

Conversely, there are primary commitments of loyalty - analogous to that extent to the patriot's commitment to country - that fail to be strong or reliable. You might have a primary loyalty to the football team of which you are a fan, for example. You may see it as your football team and you may care about it for its own sake. But that is not to imply that your concern for it is deep, and it is not to imply that you would make sacrifices out of regard for its interests. You might barely care about the football team, but to the extent to which you do, your caring could be an expression of primary loyalty.

Speaking generally, the structure of a commitment is a different matter from its strength. It is a mistake to think that whether or not a commitment is a commitment of loyalty, and whether it is a primary or a derived commitment, guarantees anything about its intensity or reliability. 
Speaking yet more generally, our motivational lives are more complex than it can first seem. You can be committed to something in any number of ways and for any number of reasons. In particular, there is not a direct line, in either direction, between identifying with something and being prepared to contribute in significant ways to its flourishing.

\section{Identity and the state}

In a globalized world, it is often - increasingly often - a mistake to regard the country as the basis for the individual's moral identity and motivation. It is unreasonable and misleading to tell the individual that her relationship with her country generates her deep moral identity, or that her moral community is coextensive with her country and politically represented by the state. But it would be equally unreasonable and mistaken to tell the individual that her moral identity is constituted simply by her relationship with humanity, or that her moral community is the world as a whole. The network of communities and the cluster of concerns that we each find as individuals are more scattered than either of those descriptions suggests.

Most of us have places where we feel at home: places of which we have special knowledge and for which we have special concern. You may have a special relationship with your town or city, or with a part of your city, or with a region or national park or landscape. If we are honest, then those places, usually, are not whole countries. If you say that you know and love Switzerland, then the truth is probably that you know and love certain parts or aspects of Switzerland. Also, for many of us, the places we know and love are scattered around the world. If you have lived in various places, in various 
countries, then you may feel that you have an intimate relationship with each of them. There may be several places around the world in which you feel at home.

Similarly, most of us have particular concerns, and most of us have particular communities of which we are part. You may have family members, friends, and wider groups of people that you know and love. You may have special concerns for particular activities - for playing tennis or drinking good wine - or for particular clubs and other organizations, or for a particular profession. You may care about certain political and social causes, and have commitments to them of sufficient strength that you take those causes personally. Again, among your concerns and communities, some will be relatively local, and some will be more scattered; in some cases, you may well feel a closer bond of community and shared interest with someone who lives on the other side of the world than with someone who lives in your street.

The state, as mentioned, remains the dominant kind of human political institution. The health of many of the things you care about will depend on the character of the state or states in which they are located. If you care about the flourishing of your region or local community, then you have reason to take an interest in your state. Similarly, you should want your state to be just and healthy if you want the activities and organizations you care about to survive and flourish. And if you want to achieve progress in the causes you care about - if you want to contribute to anything on a larger scale that will lead to a better world - then you will need to confront and try to influence states and governments. Given its power and the multiple ways in which it influences our individual and shared lives, the state has significance, of one form or another, for many of the things we care about. 
States also have significance for the health and justice of the world, and of humanity. Whether people are able to exercise self-government, whether their basic needs are met, whether their rights are respected - and whether valuable communities and ways of life survive and flourish - all depend upon the character of states. So if you have a general moral sensibility expressed as a concern for the rights and interests of all, then you will have reason to want states to be just. You will have reason, indeed, to want them to be secure and prosperous, insofar as their security and prosperity will redound to the moral benefit of particular individuals and communities. And you will have reason to want states to be moral in another sense: you will have reason to want them to act morally and make good decisions on the world stage. Whether the world is fair and peaceful depends largely on how states decide to act.

Here, then, is a kind of commitment that you may conceivably have to your state. You could care about the flourishing of your state because you take its flourishing to be important not for its own sake, or for the sake of the country that the state represents, but because of its consequences for other things for which you care. You may come to the state, so to speak, through your concerns for various places, people, organizations, and causes that rely upon the state (or other states) for their own flourishing. In your interactions with and concern for the state, you may hope not only to get the things you want for the things you care about, but also to get them on fair terms, through a process that respects the rights of all people within the country. You may care about the flourishing of your state because of the good that will follow for the things for which you have more fundamental concerns: the particular things to which you are attached, and the rights and interests of humans generally. 
This mode of concern for the state will look contrived at first. I will say more shortly about its psychological plausibility. But first, let me say something about how it compares with patriotic loyalty to country.

If you care about your state in the way described, then you do not care your country it for its own sake, and you do not need to feel any deep identity with country or pride in country. Any commitment you have to your country, of the kind just described, is not a patriotic commitment. So we have here an alternative to patriotism.

The mode of concern for country just described is not really a form of loyalty. It need not involve your seeing your country as yours, in any significant sense. What matters is not the country's being yours, but its significance for the things that are yours. And it is not a primary form of commitment to country. It is a commitment to country derived from deeper commitments to other things.

Nevertheless, it is a mode of commitment to country that can be displayed by a person who has a strong sense of her own situated identity and a strong sense of place and community. It is not the commitment of a pure cosmopolitan. You may have an unapologetically localized conception of your identity, constructed out of your relationships with particular places, people, groups, activities, organizations, and so on. Those relationships may cross national boundaries. They can nevertheless ground reasons for you to care about your state: to care for the state of which you are a citizen and in whose political life you most directly participate.

A derived commitment can be a very strong commitment, and it is possible - at least - that the commitment to country that I am describing could be profound and thoroughgoing. You may not care about the country for its own sake, but you might 
nevertheless be prepared to make sacrifices for your state and to play your part in keeping it healthy - to defend the state and to participate in its decision-making - because you take it to have great, even if derived, value.

While your commitment to country may be great, and indeed as great as the commitment of the patriotic citizen, it will be different in structure from the commitment of the patriot, and that will have some consequences for how you think of your country and what you are prepared to do for it. First, in approaching your country, you are less likely to think of it as the one special country that is yours and more likely to recognize it as one country among others; with your scattered pattern of more fundamental concerns, you are more likely to have an awareness of your and your country's place in the world and of your country's strengths and weaknesses relative to others. This, probably, will temper your willingness to serve your country when it is in competition with other countries. Lacking the intense first-level devotion of the patriot, you are less likely to think it a matter of absolute moral urgency that your country succeed when its interests clash with the interests of others.

Second, given the structure of your commitment to your country, your willingness to act for it will be conditional. As you might refuse to help your political party in a campaign for a cause in which you do not believe, you might refuse to serve your state when you judge that its policies do not serve the basic rights and interests of its citizens (or other people), when it abandons the regions or people or other things to which you are committed, or when it embarks upon a war of which you disapprove. (You might, of course, choose to support the state even when its harms the things you care about, on the 
grounds that keeping the state functioning and unified will be best in the long run, given your deeper concerns. But that, still, is a conditional commitment.)

The form of commitment to country that I am trying to describe here can be called "worldly citizenship." It is "worldly" because it involves understanding your country as one among others. It is not "world citizenship" because the form of identity underlying it is not an identity with humanity or with the world as a whole. It is "citizenship," or so I claim, because it designates a cluster of beliefs, feelings, and motivations that can generate robust concern for a state and can be relied upon to produce acts that contribute to the state's flourishing. In closing the paper, I will say a little about why I think worldly citizenship is attainable and why I think it is desirable.

\section{The case for world citizenship}

\section{Immigrant citizens}

Consider a person who moves from one country to another and becomes a good citizen of the new country. Such people are common. Suppose that you leave India and move to New Zealand, where you stay, and where you eventually become, formally, a citizen. You may still think of India as home. It may be difficult for you to think of yourself as a New Zealander, really, and still more difficult to think of yourself as a New Zealand patriot: any patriotic feelings you have may be directed squarely at India. But you could be a model citizen of New Zealand, involved in community and political life, respecting the state and its laws, and looking after those around you.

\footnotetext{
${ }^{8}$ I approach worldly citizenship through a different question in my 'Worldly Citizens: Civic Virtue without Patriotism,' in Gillian Brock (ed.) Cosmopolitanism versus Noncosmopolitanism (Oxford University Press, 2013), pp. 239-254.
} 
Good immigrant citizens, it seems to me, often exhibit the structure of commitments that characterize worldly citizenship. Upon moving to a new country, you cannot claim to know the country, but you can come to know parts of it and aspects of it. An immigrant to New York may find America a large and foreign place, while yet coming to feel at home in New York; an immigrant to a new country may come to know and love a school or a sports club or a neighborhood or a workplace. As an immigrant, you can also recognize the importance that your new country and its government have for your prospects and for the places and organizations and forms of life within the country for which you care. If you are an immigrant who also has a general concern for other humans, you can also be moved to contribute to good causes in the new country, to get politically involved, and generally to act well towards those you find around you.

The source of such good immigrant citizenship is not detached cosmopolitanism, though it is partly an expression of a general regard for others and a preparedness to act well towards other humans in whatever circumstances are faced. Its source is, partly, a commitment to the things within the new country that the new citizen comes to love things distinct from the country itself.

The structure of motivation found in immigrant citizens can be replicated in citizens who are not immigrants. You do not need to be an immigrant to a country in order to value the country and make a commitment to the state out of regard for the good it does for the more localized things you care about and for its role in advancing human rights and interests generally. The kind of citizenship that I am trying to describe is not too contrived. It can be found around us, most obviously in good immigrant citizens, but also in others. 


\section{Nurturing worldly citizenship}

There is a long tradition of patriotic education, intended to produce good citizens by inculcating patriotic beliefs, feelings, and motives. If we are to take worldly citizenship as our alternative ideal, then education for citizenship will have different goals.

The first task in educating worldly citizens is to encourage them to recognize and appreciate the different places and other influences that make them who they are. Instead of trying to parlay local attachments into a single attachment to the country, we should embrace local and particular identities, in their various different forms. Children should be taught to identify the things they know best and to understand the influence that those things have upon their identities.

The second task is to inculcate genuinely humanitarian beliefs and sentiments: an understanding of what humans have in common; an understanding that there is a large world full of people living their own lives, similar in some ways but different in others; and concern and respect for the rights and interests of all. This is a foundation for good citizenship that can be transferred between states. Under any circumstances, part of what it means to be a good citizen is just to act well towards the humans you find around you.

The third task of an education for worldly citizenship is to explain how the home country works, emphasizing the importance of the state for the health of local communities and places, and for general human rights and interests. The goal is to create citizens who can see how important the state is, given their deeper identities and 
concerns, and hence can find motivation to support the state and to try to influence it for the best.

Is it possible for an educational system to perform these three tasks? And if it does, will it tend to produce good citizens as a result? I cannot claim to know, but I do think that there is a coherent and in principle achievable conception of good citizenship around which the three tasks can be organized, and - importantly - that none of the three tasks need involve artificiality or deception or trying to build people in the modern world into something they can never be.

\section{Self-knowledge, the value of the state, and what it is like to be a good citizen}

In a globalized world, we cannot presume that the identities of individuals are constituted by their connections with their countries or that it is possible to form individuals whose identities will be constituted by such connections. But that does not mean, as I have stressed, that we are all just humans now, or that each of us has the world - the undifferentiated world - as her home. Something other than patriotic citizenship and world citizenship is required.

A first advantage of the ideal of worldly citizenship, I think, is that it is compatible with an accurate understanding of self. The worldly citizen is able to see herself, by understanding the scattered networks, communities, and institutions that make her the person she is.

If I am correct, in addition, in saying that it is possible for the worldly citizen to have a robust and reliable motivation to perform acts that contribute to the flourishing of the state, then the ideal of worldly citizenship can bring together the two approaches to 
the question of good citizenship, in ways appropriate for contemporary conditions. The worldly citizen can be the kind of citizen wanted by the state, because she can give the state what it needs from its citizens in order to flourish; the worldly citizen can support the state and find motivation to participate in its government. The worldly citizen can also be a person who flourishes in her role as citizen, because she can act well within that role while understanding herself accurately, without embracing a purely manufactured identity, and without having misguided beliefs or misplaced motives.

Another virtue of worldly citizenship is that the worldly citizen's conditional commitment to the state is just the kind of commitment that the state deserves. States are not intrinsically valuable and do not demand sacrifices just for their own sakes. The state's role is to serve the individuals and communities and places within its juridstiction, and to contribute constructively to the world more broadly. A citizen who holds the state to account for its treatment of the things within the state for which she cares, and for its performance in serving the rights and interests of people generally, thereby sees the state as it should be seen. A citizen should not be dedicated to the state no matter what and should not consider it unthinkable that the state should cease to deserve her support or that it should go out of existence. A good citizen does not give her state the benefit of the doubt or hold back on criticizing it. To that extent, a person will be a better citizen if her commitment to her state is derived from her commitment to more fundamental values and principles: ones that really do matter. A citizen who identifies with the country in the first instance will find it harder to see her state and its faults clearly.

The conditions we face in a globalized world pose a challenge to traditional ways of thinking about good citizenship. The model of the good citizen whose identity is 
deeply entangled with her connection to country, and whose commitment to country is a matter of primary loyalty, is not, I think, sustainable. The world is too interconnected and the forces that form our identities - whether we realize it or not - are too internationalized. But that does not mean that good citizenship is less important, and it need not mean that good citizenship is unattainable. A mature citizen in the globalized world is someone who understands her particular formative relationships, who has a general humanitarian moral sensibility, and who understands and values the state for what it is: not a moral community, not a deep source of moral identity, not an organic or intrinsically valuable institution, but instead a vital instrument through which the things that really matter can be served. 